\title{
Sintesis senyawa 2,4-Dihidroksiasetofenon dan Uji Aktivitasnya sebagai Antioksidan
}

\section{Synthesis of 2,4-Dihydroxyacetophenone Compound and its Antioxidant Activity Assay}

\begin{abstract}
ABSTRAK
Antioksidan sangat penting dalam menjaga kesehatan tubuh manusia karena mampu meredam radikal bebas. Asetofenon dan turunannya dilaporkan berpotensi sebagai antioksidan. Tujuan penelitian ini adalah untuk mengetahui aktivitas antioksidan senyawa 2,4dihidroksiasetofenon hasil sintesis dari resorsinol.

Penelitian dilakukan dengan mensintesis senyawa 2,4-dihidroksiasetofenon melalui reaksi asilasi Friedel-Crafts dari resorsinol. Senyawa hasil sintesis dianalisis menggunakan kromatografi gas, spektrometer massa, spektrofotometer infra merah, dan analisis antioksidan dilakukan menggunakan metode DPPH.

Hasil sintesis berupa padatan jingga yang memiliki persentase yield sebesar $86,14 \%$. Hasil analisis menunjukkan bahwa senyawa tersebut adalah senyawa 2,4-dihidroksiasetofenon. Senyawa hasil sintesis memiliki aktivitas antioksidan dengan nilai $I_{50}$ sebesar 36,72 ppm.
\end{abstract}

Kata kunci : antioksidan; 2,4-dihidroksiasetofenon; DPPH

\section{ABSTRACT}

Antioxidant is very important to keep human's health because of its capability to reduce free radical. Acetophenone and its derivates are reported as potential antioxidant. The aim of this research was to find antioxidant activity of 2,4-dihydroxyacetophenone compound synthesized from resorcinol.

The research was performed by synthesizing 2,4-dihydroxyacetophenon through FriedelCrafts acylation from resorsinol. The structure of the compound was elucidated using gas chromatography, mass spectrometer, infrared spectrophotometer, and antioxidant test was using DPPH method.

The results showed that product was succesfully synthesized. Yellowish-orange solid was obtained from synthesis with $86,14 \%$ of yield and confirmed as 2,4-dihydroxyacetophenone. The product showed weak antioxidant activity with $36,72 \mathrm{ppm}$ of $\mathrm{IC}_{50}$.

Keywords : antioxidant; 2,4-dihydroxyacetophenon; DPPH

\section{PENDAHULUAN}

Penyakit degeneratif dam penuaan dini merupakan implikasi akibat stress oksidatif yang ditimbulkan oleh terakumulasinya radikal bebas dalam jaringan tubuh. Hal ini terjadi karena adanya nutrisi buruk, tingginya stress fisik maupun psikologis, paparan polutan, paparan berlebih dari antibiotika dan obat lainnya menyebabkan semakin banyaknya radikal bebas dalam tubuh. (Moelyono et al., 2000).

Antioksidan merupakan suatu senyawa yang mampu menghambat oksidasi molekul lain (Rohman \& Riyanto, 2005). Tubuh manusia tidak mempunyai cadangan antioksidan dalam jumlah berlebih, sehingga jika terjadi paparan radikal berlebih maka tubuh membutuhkan antioksidan eksogen (Sunarni, 2005). 
Senyawa asetofenon dan turunannya mampu menghambat reaksi oksidasi melalui mekanisme penangkapan radikal (radical scavenging) dengan cara menyumbangkan satu elektron pada elektron yang tidak berpasangan dalam radikal bebas sehingga banyaknya radikal bebas menjadi berkurang (Pokorny et al. 2001).

\section{METODE PENELITIAN}

Bahan uji yang digunakan dalam penelitian ini adalah senyawa resorsinol dan asam asetat glasial, selain itu reagen, yaitu $\mathrm{ZnCl}_{2}$ (teknis), DPPH, etanol p.a. , asam klorida (teknis) , $n$ heksana p.a., etil-asetat p.a., kloroform p.a., aqua destilata (Ramayana Laboratorium).

Alat-alat yang digunakan adalah peralatan gelas laboratorium, termometer, satu set alat pengaduk magnet (magnetic stirrer), timbangan analitik. Untuk keperluan analisis digunakan alat Spektrofotometer UVVis (Shimadzu 1800 UV-VIS).

\section{Sintesis 2,4-dihidroksiasetofenon}

Asam asetat glasial sebanyak 0,1 mol dimasukkan dalam labu leher tiga dan ditambah katalis $\mathrm{ZnCl}_{2} \quad 0,05$ mol. Campuran direfluks selama 45 menit. Resorsinol sebanyak 0,04 mol ditambahkan perlahan ke dalam campuran dan direfluks. Selanjutnya direkristalisasi dengan memanaskan padatan dalam campuran $\mathrm{HCl}$ : metanol : air kemudian disaring. Hasil diuji kemurniannya dengan kromatografi lapis tipis dan kromatografi gas selanjutnya dielusidasi dengan spektrometer massa dan spektrofotometri infra merah.

\section{Penentuan Panjang Gelombang Maksimum DPPH}

Sebanyak 2,0 ml larutan DPPH ditambah 2,0 ml metanol, dikocok homogen dan diamati serapannya pada rentang $\lambda$ 400-600 $\mathrm{nm}$ dengan menggunakan blanko metanol. Sebelum dilakukan penentuan panjang gelombnag maksimum tersebut terlebih dahulu ditetapkan operating time untuk mengetahui kestabilan larutan DPPH.

\section{Uji Aktivitas Antioksidan}

Penentuan aktivitas antioksidan dengan memipet sebanyak $2 \mathrm{~mL}$ larutan uji dan ditambahkan ke dalam vial dan dihomogenkan. Campuran diinkubasi selama operating time yang telah diperoleh dan dibaca absorbansinya pada panjang gelombang maksimum. Aktivitas antioksidan sampel ditentukan oleh besarnya serapan radikal DPPH melalui perhitungan persentase inhibisi serapan DPPH dengan menggunakan rumus:

$$
\% \text { inhibisi }=\left|\frac{\text { Absorbansi kontrol-Absorbansi sampel }}{\text { Absorbansi kontrol }} \times 100 \%\right|
$$




\section{PEMBAHASAN}

2,4-dihidroksiasetofenon di sintetis melalui reaksi asilasi Friedel-Crafts.
Asam asetat berperan sebagai senyawa pengasilasi dan $\mathrm{ZnCl}_{2}$ sebagai katalis asam Lewis.

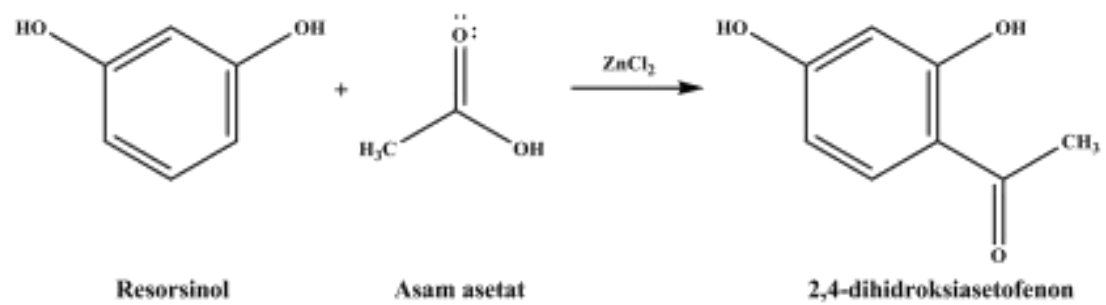

Gambar 1. Reaksi sintesis senyawa 2,4-dihidroksiasetofenon

Hasil sintesis berupa padatan berwarna jingga dengan persentase yield $86,14 \%$, memiliki titik lebur 143 ${ }^{\circ} \mathrm{C}$. Senyawa ini larut dalam etanol dan praktis tidak larut dalam air.

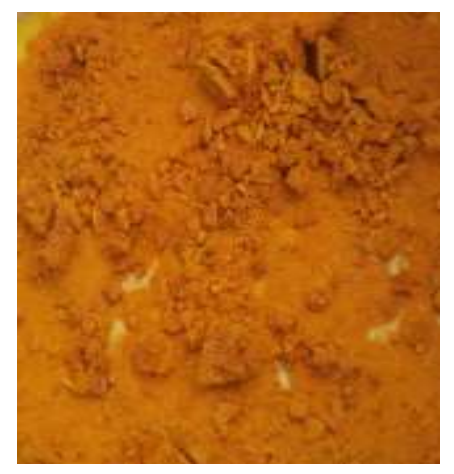

(2)
Senyawa hasil sintesis dikatakan berhasil secara KLT karena memberikan satu bercak tunggal pada sinar UV $254 \mathrm{~nm}$ dengan harga Rf 0,84.

Gambar 2. Padatan senyawa 2,4-dihidroksiasetofenon.

Gambar 3. Profil KLT 2,4-dihidroksiasetofenon.

Keterangan : A. Asam asetat glasial, B. Resorsinol, C. Senyawa target

Analisis senyawa hasil sintesis dengan kromatografi gas menunjukkan bahwa senyawa hasil sintesis memiliki puncak tunggal dengan kemurnian mencapai $100 \%$ pada waktu retensi $\left(t_{R}\right)$ 11,503 menit (Gambar 4).Kemurnian senyawa hasil sintesis diperkuat dengan data spektra massa (MS) yang menunjukkan ion molekular $\left(\mathrm{M}^{+}\right)$yang sesuai dengan berat molekul senyawa 2,4-dihidroksiasetofenon yaitu 152 $\mathrm{g} / \mathrm{mol}$ (Gambar 5.

Serapan pada bilangan gelombang $3302 \mathrm{~cm}^{-1}$ menunjukkan gugus $-\mathrm{OH}$ alkohol dengan vibrasi rentang. Serapan pada $3034 \mathrm{~cm}^{-1}$ menunjukkan vibrasi ulur $=\mathrm{C}-\mathrm{H}\left(\mathrm{Csp}^{2}\right)$ akibat adanya gugus tak jenuh. Gugus tak jenuh ini diperkuat oleh serapan vibrasi ulur pada $1631 \mathrm{~cm}^{-1}$ yang 
disebabkan oleh gugus $\mathrm{C}=\mathrm{C}$. Serapan kuat pada $1631 \mathrm{~cm}^{-1}$ dengan overtonenya pada 3302 timbul dari gugus karbonil, $\mathrm{C}=\mathrm{O}$. Pergeseran ke daerah bilangan gelombang yang lebih rendah menunjukkan bahwa gugus karbonil dari senyawa hasil sintesis terkonjugasi dengan cincin aromatis dan ikatan rangkap $-\mathrm{C}=\mathrm{C}$ cenderung memiliki karakter ikatan tunggal sehingga mudah mengalami stretching dari pada ikatan rangkap dua (Gambar 6).

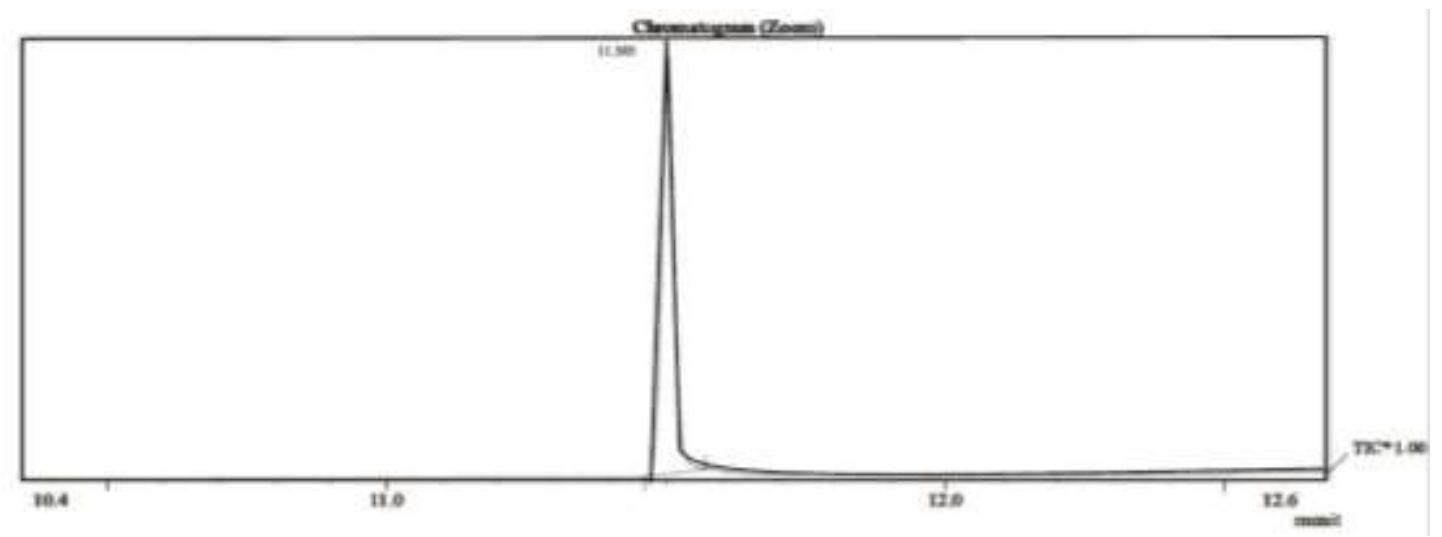

Gambar 4. Kromatogram GC senyawa 2,4-dihidroksiasetofenon.

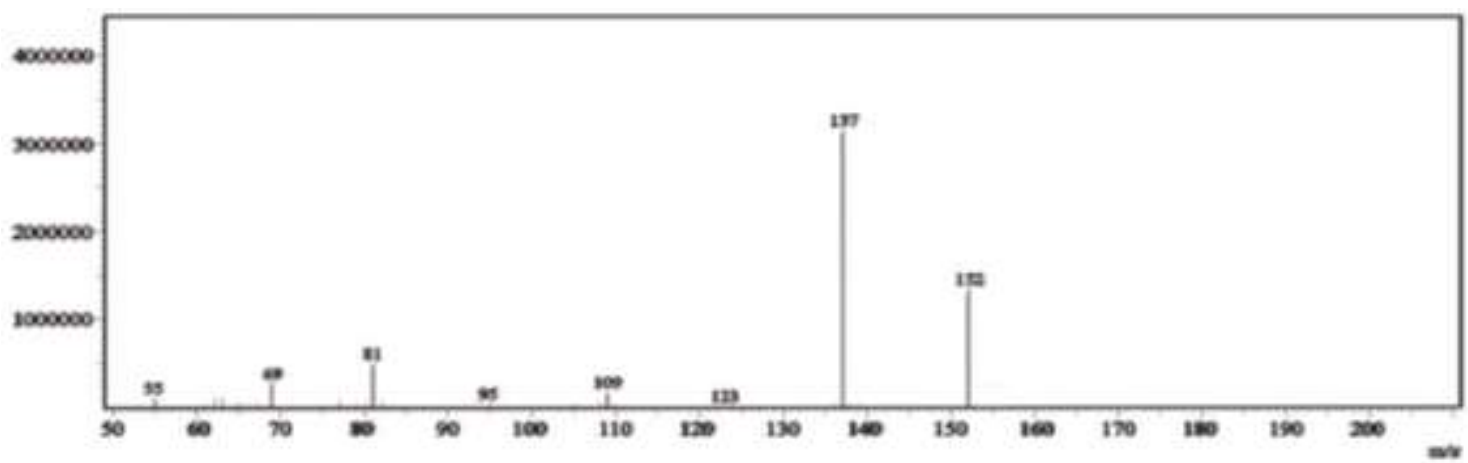

Gambar 5. Spektra massa senyawa 2,4-dihidroksiasetofenon.

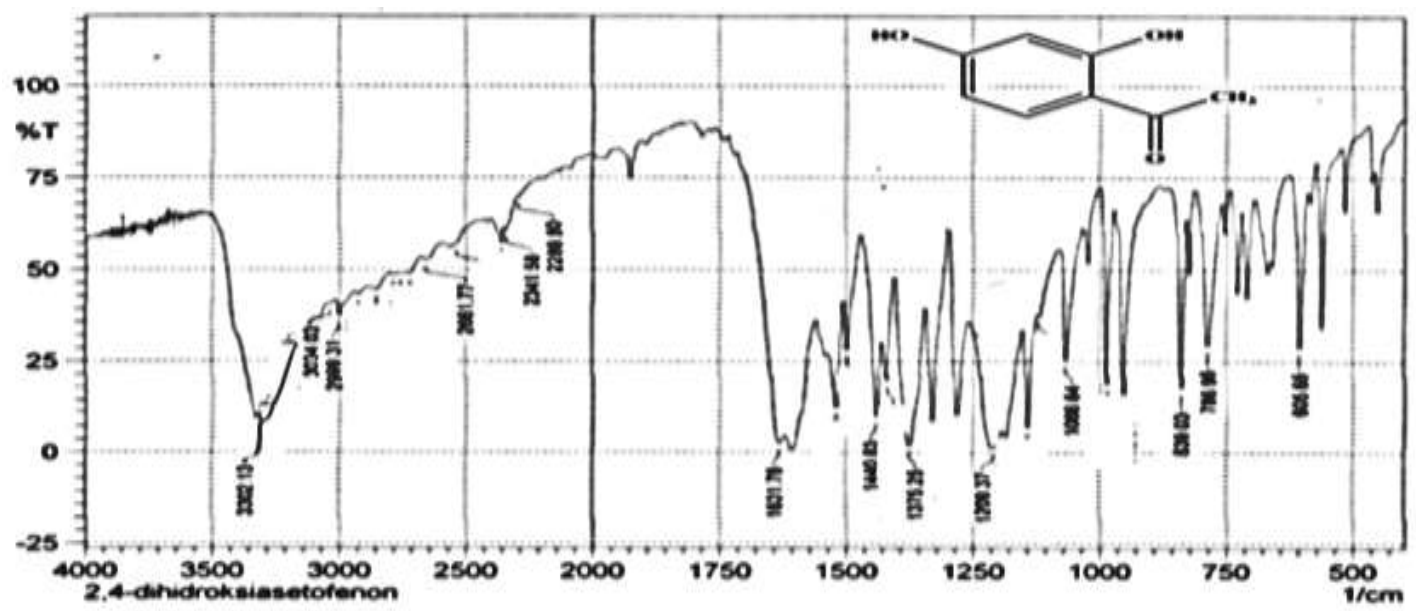

Gambar 6. Spektra IR 2,4-dihidroksiasetofenon. 


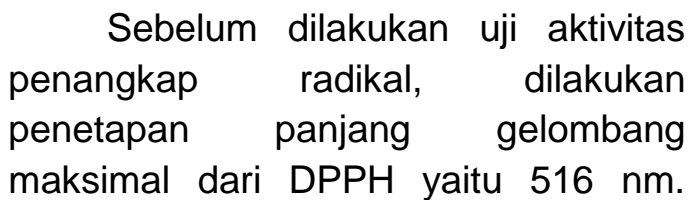
Panjang gelombang maksimal inilah yang selanjutnya digunakan untuk pembacaan serapan. Panjang gelombang yang menunjukkan senyawa mempunyai serapan yang paling besar. Panjang gelombang maksimal digunaka karena pada panjang gelombang maksimal kesalahan relatif pembacaan paling kecil.Waktu reaksi yang digunakan adalah pada menit ke 25 dengan alasan bahwa pengamatan serapan pada menit tersebut sudah cukup untuk memberikan kesempatan terjadi reaksi. Hasil uji aktivitas penangkap radikal dapat dilihat pada Gambar 6 .

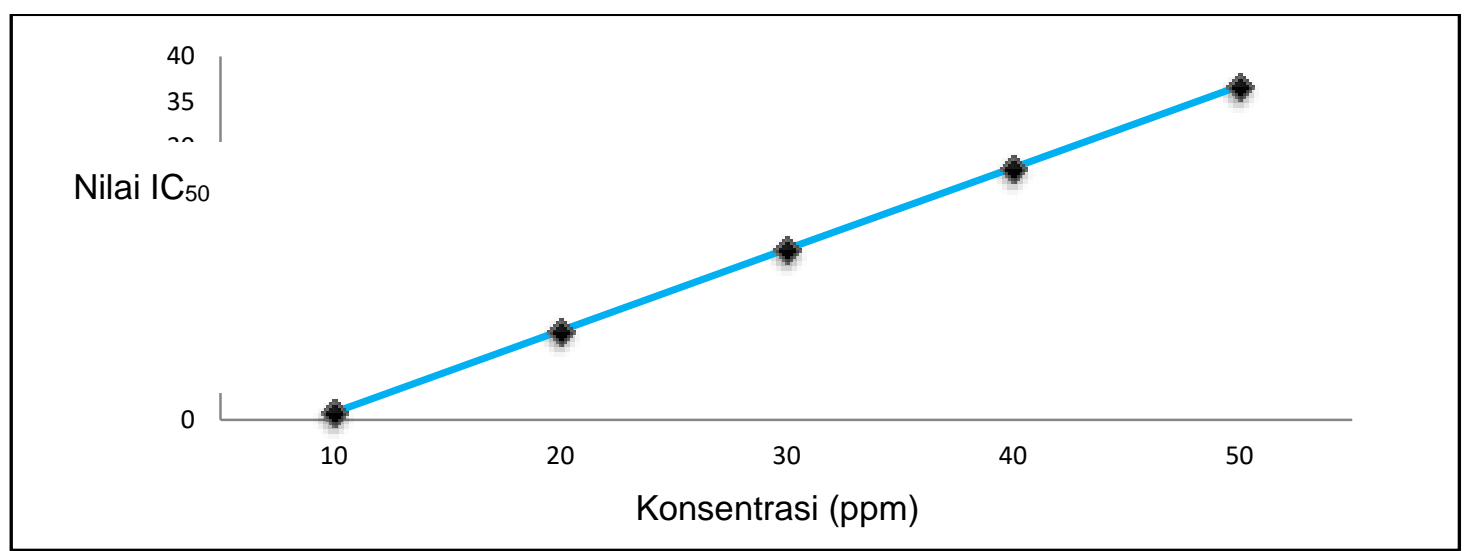

Gambar 7. Grafik hubungan antara konsentrasi 2,4-dihidroksiasetofenon dengan aktivitas antioksidan

Berdasarkan grafik hubungan $9,0560+1,1151 \mathrm{X}$, dengan nilai $r=$ antara konsentrasi senyawa dengan 9,056 dapat diketahui nilai $I_{50}$ aktivitas penangkapan radikal DPPH, senyawa 2,4-dihidroksiasetofenon didapatkan persamaan regresi linier $\mathrm{Y}=$ sebesar 36,72 ppm.

\begin{tabular}{cccc}
\hline $\begin{array}{c}\text { Konsentrasi } \\
\text { larutan uji(ppm) }\end{array}$ & Absorbansi & $\begin{array}{c}\% \text { Inhibisi } \\
(\%)\end{array}$ & $\begin{array}{c}\text { Nilai IC50 } \\
(\mathbf{p p m})\end{array}$ \\
\hline 10 & 0,768 & 20,3320 & 0,847 \\
\hline 20 & 0,684 & 29,0456 & 9,814 \\
\hline 30 & 0,532 & 44,8133 & 18,782 \\
\hline 40 & 0,429 & 55,4979 & 27,750 \\
\hline 50 & 0,358 & 62,8631 & 36,718 \\
\hline
\end{tabular}

Tabel 1. Grafik hubungan antara konsentrasi 2,4-dihidroksiasetofenon dengan aktivitas antioksidan

Proses penangkapan radikal DPPH pertama kali terjadi pada gugus hidroksil pada cincin benzena. Dimana gugus hidroksil tersebut kemungkinan besar akan mengalami reaksi homolitik, sehingga atom hidrogen akan terabstraksi karena adanya radikal DPPH. Pada 2,4-dihidroksiasetofenon, gugus hidroksi merupakan gugus pendorong elektron yang sangat 
berpengaruh dalam proses penyebaran elektron atau konjugasi ke dalam cincin benzena walaupun memiliki efek induksi negatif tetapi efek resonansi lebih kuat. Elektronnya beresonansi sampai ke luar cincin benzena, yaitu sampai gugus karbonil. Senyawa 2,4dihidroksiasetofenon hanya mempunyai satu gugus karbonil pada gugus siklopentanon sehingga hanya elektron dari satu sisi gugus hidroksil yang mengalami reaksi homolitik yang bisa di bawa ke gugus karbonil sehingga 2,4dihidroksiasetofenon mempunyai aktivitas penangkapan radikal DPPH yang kecil.

\section{KESIMPULAN}

Senyawa 2,4-dihidroksiasetofenon berhasil disintesis dan senyawa tersebut mempunyai aktivitas sebagai antioksidan dengan nilai IC50 sebesar $36,72 \mathrm{ppm}$.

DAFTAR PUSTAKA

Moelyono M.W, Ahmad M, Ully F, 2000, Aktivitas Antioksidan Invitro Ekstrak Metanol Kulit Kayu angkasa, Prosiding Sem.NasXVII : 555-558

Pokorny, J., Yanishlieva, N., and Gordon, M., 2001, Antioxidant in Food: Practical Aplications, CRC press, New York

Sunarni, T., 2005, Aktivitas Antioksidan Penangkap Radikal Bebas Beberapa kecambah Dari Biji Tanaman Familia Papilionaceae, Jurnal Farmasi Indonesia, 2(2), 53-61.

Rohman A, Riyanto S. 2005. Daya antioksidan ekstrak etanol daun kemuning (Murraya paniculata (L) Jack) secara In Vitro. Jurnal Farmasi Indonesia, 16(3):136 140. 